\title{
27. PALYNOLOGICAL ASPECTS OF SITE 767 IN THE CELEBES SEA ${ }^{1}$
}

\author{
W. A. (Sander) van der Kaars ${ }^{2}$
}

\begin{abstract}
A palynological study of samples from Ocean Drilling Program Site 767 in the Celebes Sea indicates the presence of extensive wetlands (mangrove forests, coastal and lowland swamps) in the area during the-middle and late Miocene. At the start of the late Pleistocene the montane vegetation expanded, probably as a consequence of tectonic upheaval.
\end{abstract}

\section{INTRODUCTION}

Site 767 of the Ocean Drilling Program is located in the Celebes Sea $\left(4^{\circ} 47.50^{\prime} \mathrm{N}, 123^{\circ} 30.20^{\prime} \mathrm{E}\right)$ at a water depth of 4905 $\mathrm{m}$ (see Fig. 1). The sediments consist mainly of volcanic clayey silt in the upper $260 \mathrm{~m}$ below seafloor (mbsf), with carbonate silt from 150 to $260 \mathrm{mbsf}$; volcanic silty claystone and claystone from 260 to 405 mbsf; claystone from 405 to 790 mbsf (Rangin et al., 1990).

The sporomorph content from 80 core-catcher samples and 96 core samples from Site 767 was examined (for an overview of the analyzed samples see Appendix). The purpose of this preliminary study of the sediments recovered from Site 767 was to have a general overview of the pollen stratigraphy and regional paleoenvironmental evolution, and to evaluate the suitability of the sporomorph assemblages for more detailed paleoecological and biostratigraphic research. Palynological-paleoecologial studies in the area around the Celebes Sea have been limited mainly to Borneo (Anderson and Muller, 1975; Germeraad et al., 1968; Muller, 1964; 1966; 1968; Morley, 1981).

\section{METHODS}

Palynological samples were processed using the following standard technique. A $3-\mathrm{cm}^{3}$ sample was suspended successively in Na-pyrophosphate $10 \%(\mathrm{HCl} 10 \%$ was used for calcareous sediments), hot Na-pyrophosate $20 \%$ and $\mathrm{Na}$-pyrophosphate $10 \%$; followed by bromoform separation and safranin staining. Lycopodium marker spores were used. Slides were mounted with glycerol jelly, and the cover-slips were sealed with paraffin.

From most samples one slide was analyzed. Pollen and fern spores were counted; the minimum count was 30 pollen grains. If less than 30 pollen grains were counted the sample was not used in the summary diagram, but if more than 5 pollen were counted and the number of pollen and fern spores was more than 50 , the pollen-spore ratio of that sample is given.

For this study pollen taxa were placed in the following ecological groups.

\footnotetext{
'Silver, E. A., Rangin, C., von Breymann, M. T., et al.,1991. Proc. ODP, Sci. Results, 124: College Station, TX (Ocean Drilling Program).

${ }^{2}$ Hugo de Vries-Laboratory, Department of Palynology and Palaeo/Actuo-ecology, University of Amsterdam, Kruislaan 318, 1098 SM Amsterdam, The Netherlands.
}

\section{Montane Vegetation}

Araucaria-Agathis, Lithocarpus-Castanopsis (low montane) Dacrycarpus, Dacrydium, Phyllocladus, Podocarpus (mid- to upper montane).

\section{Mangrove Vegetation}

Barringtonia, Brownlowia, Rhizophora, Sonneratia.

\section{Lowland Vegetation}

Caesalpina, Calophyllum, Casuarina, Eugenia, Euphorbiaceae, Ilex, Malvaceae, Melanorrhoea, Palmae, Pandanus, Proteaceae, Rubiaceae, Sapindaceae, Sapotaceae, Shorea, Terminalia, Urticaceae/Moraceae. Other, mostly unidentified, pollen types that occurred sporadically and in very low numbers were also placed in this ecological group.

\section{RESULTS}

\section{ODP Site 767 Core-Catcher Samples}

Evaluation of core-catcher samples from the Celebes Sea Site 767 indicate that Hole $767 \mathrm{~A}$, Cores $124-767 \mathrm{~B}-1 \mathrm{H}$ through 124 $767 \mathrm{~B}-13 \mathrm{X}\left(0-200\right.$ pollen/ $\left.\mathrm{cm}^{3}\right)$ and Cores $124-767 \mathrm{~B}-42 \mathrm{X}$ to $124-$ 767B-64X (0-2000 pollen/ $\left.\mathrm{cm}^{3}\right)$ from Hole 767B probably contain enough sporomorphs for pollen analysis, whereas Cores 124-767B-14X through 124-767B-41X and Cores 124-767B-65X through 124-767B-78X from Hole 767B and Hole 767C seem to be barren of palynomorphs.

A summary diagram from the core-catcher samples (Fig. 2A) shows that the pollen assemblages in the upper $120 \mathrm{~m}$ from Hole 767B (Cores 124-767B-1H through 124-767B-13X) are dominated by montane and lowland taxa. The fern spores/pollen ratio is high, approximately $80 / 20$. Gymnosperms from the mid- to upper montane vegetation (1500 to $3500 \mathrm{~m}$ altitude) account for some $90 \%$ of the montane pollen grains. Besides pollen and fern spores the organic matter comprises denticles, some plant remains, fungal spores, diatoms, radiolarians, dinoflagellate cysts, and, in some of the samples, abundant foraminifer linings.

From 400 to 610 mbsf (Cores 124-767B-42X through 124767B-64X from Hole 767B) mangrove pollen (mainly Rhizophora) and lowland taxa dominate the pollen assemblages in the summary diagram. The fern spores/pollen ratio is roughly $50 / 50$. Montane taxa percentages increase uphole in this interval from $5 \%$ to $20 \%$. Elements from the low montane vegetation (500- to 1500 -m altitude) make up some $80 \%$ of the montane pollen grains. The organic fraction contains abundant well-preserved plant remains (often coarse, 1000-3000 $\mu \mathrm{m}$ ), fungal spores, some dinoflagellate cysts, and foraminifer linings. 


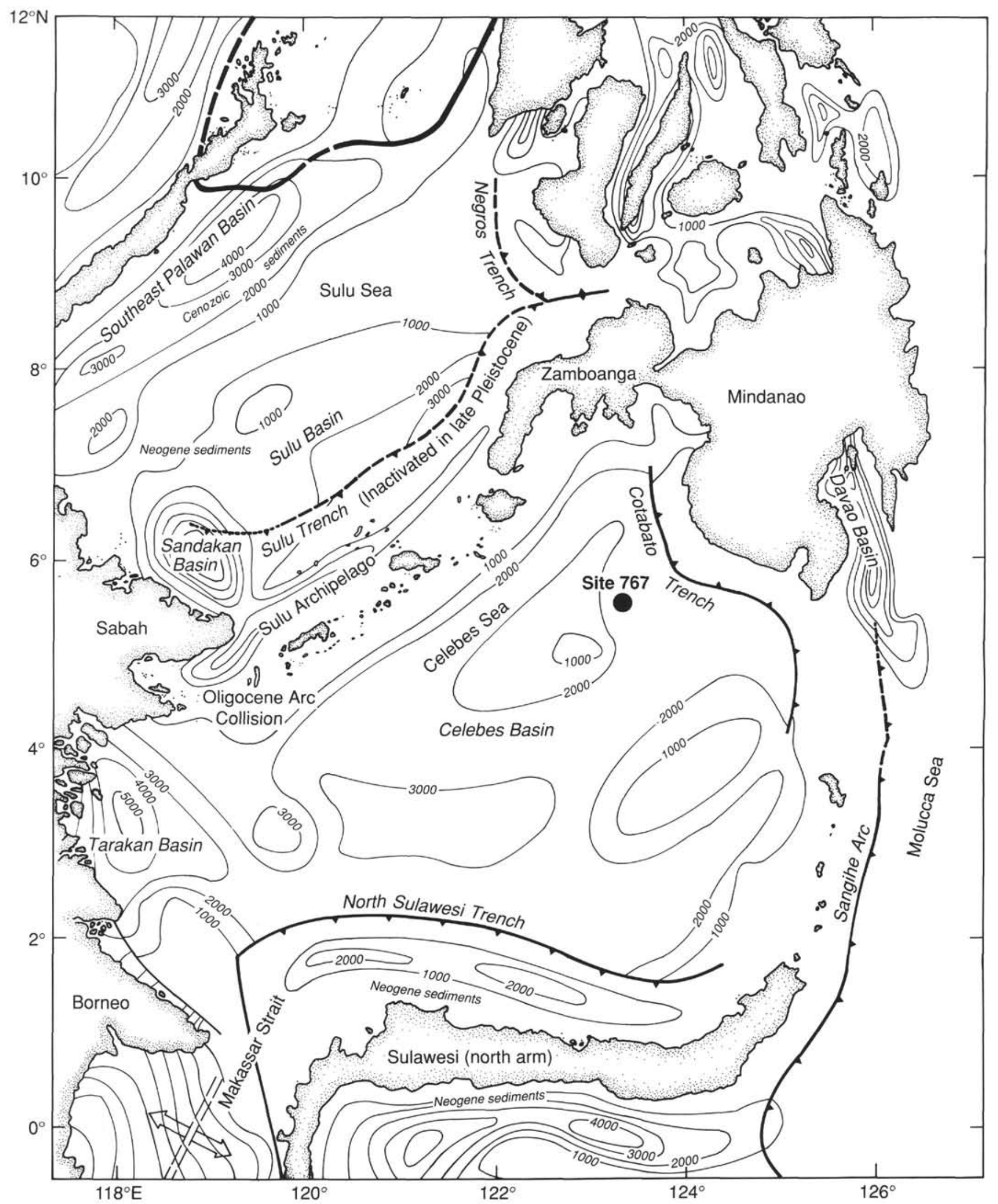

Figure 1. Location of ODP Site 767. 


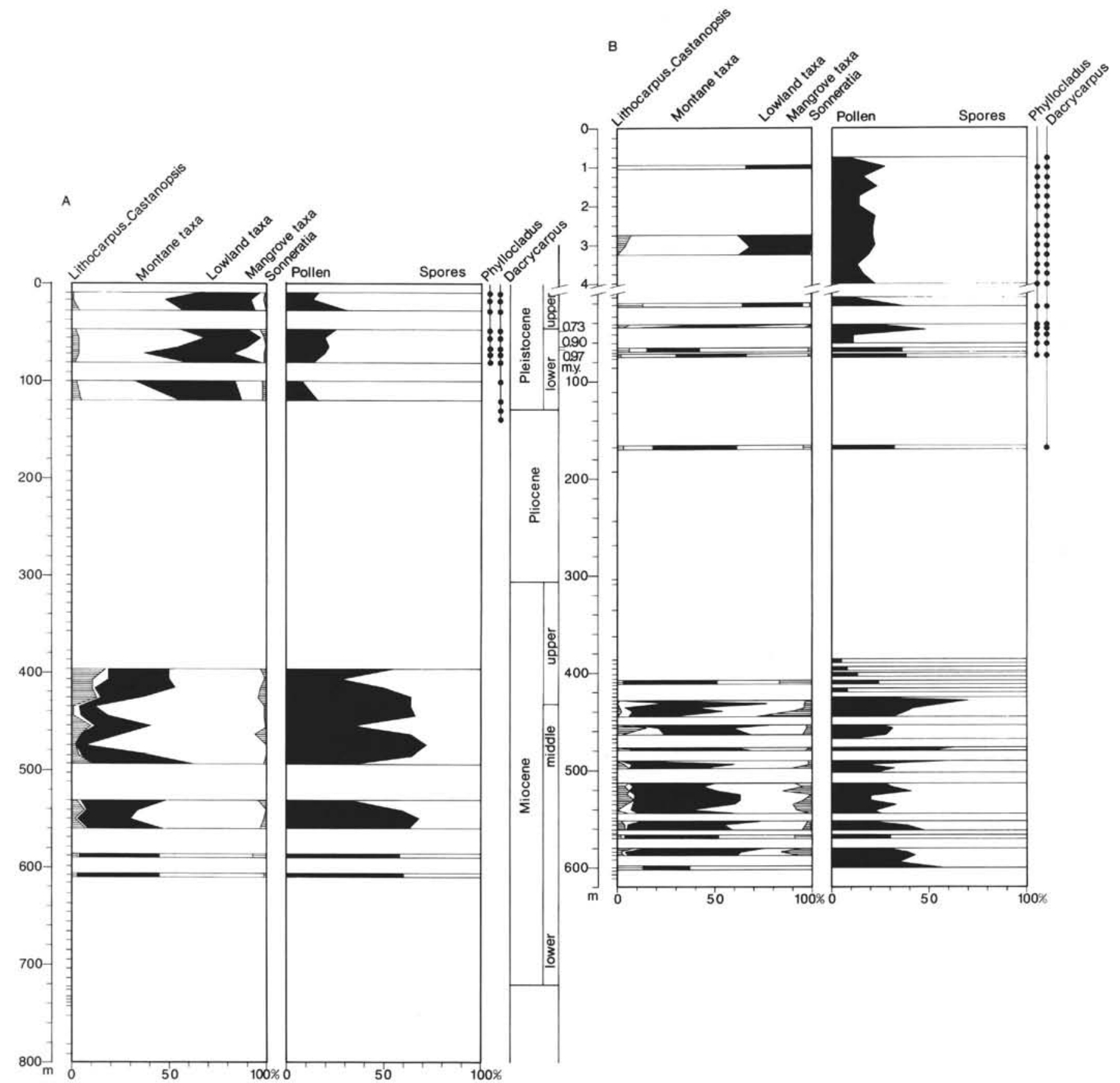

Figure 2. Site 767 summary diagram showing the percentages of important ecological groups, pollen and fern spores ratio, and the biostratigraphic range of Phyllocladus and Dacrycarpus. (A) core-catcher samples from Site 767 and (B) core samples from Site 767. Time scale is from Rangin et al. (1990).

Dacrycarpus pollen grains first occur in Sample 124-767B15X, CC, Phyllocladus grains in Sample 124-767B-9H, CC.

\section{ODP Site 767 Core Samples}

Additionally, 93 core samples from the two intervals indicated as pollen-rich by the core-catcher samples have been analyzed. Core sample results were poorer than core-catcher sample results. The 16 samples taken in the upper $4 \mathrm{~m}$ of Core 124-767B-1 $\mathrm{H}$ were barren or had very low pollen counts ( 1 to 47 pollen per slide). From the other 77 samples 29 were barren, 12 had less than 30 pollen per slide, 27 were useful ( 30 to 90 pollen per slide) and 9 had more than 100 pollen per slide.

In the summary diagram (Fig. 2B) the character of the pollen assemblages changes at approximatly $44 \mathrm{mbsf}$. In Sample 124$767 \mathrm{~B}-5 \mathrm{H}-4,25-26 \mathrm{~cm}$, and further uphole, montane and lowland taxa dominate; the fern spores/pollen ratio is approximately $80 / 20$. Grains from the mid- to upper montane vegetation account for $85 \%$ of the montane pollen score.

In Sample 124-767B-5H-6, 17-22 cm, and further downhole, mangrove taxa (Rhizophora and Sonneratia) and lowland taxa 
dominate. The fern spores/pollen ratio varies from 50/50 to $90 / 10$. Pollen from the low montane vegetation (500 to $1500 \mathrm{~m}$ altitude) on average make up $65 \%$ of the montane pollen count. Higher mid- to upper montane ( 1500 to $3500 \mathrm{~m}$ ) counts occur from 430 to $460 \mathrm{mbsf}$ and from 44 to $170 \mathrm{mbsf}$.

Dacrycarpus pollen grains first occur in Sample 124-767B$19 \mathrm{X}-2,35-40 \mathrm{~cm}$, Phyllocladus pollen grains in Sample 124767B-7H-4, 26-27 cm.

\section{DISCUSSION}

This study reveals that, during the middle and late Miocene and probably also during the Pliocene and early Pleistocene, an extensive mangrove vegetation was present around the Celebes Sea Site 767 (see Fig. 2). Many taxa described by Anderson and Muller (1975) from Holocene peat and Miocene coal deposits from northwest Borneo were also found, indicating that coastal and lowland peat swamps were present in the middle and late Miocene. The high mangrove (Rhizophora) percentages, on average around $50 \%$ but in some samples more than $90 \%$, indicate that pollen grains were derived from the mangrove vegetation, probably within $60 \mathrm{~km}$ of the shoreline, as in general at larger distance from the mangrove source Rhizophora percentages become much lower (see Muller, 1959; van der Kaars, 1989; Somboon, 1990).

As many of the montane taxa are prolific pollen producers and their pollen grains often travel over large distances (see van der Kaars, 1990), the low montane pollen scores may indicate that during the middle and late Miocene the montane vegetation around Site 767 was very limited. In the Pliocene and early Pleistocene the montane vegetation increased slightly.

At the start of the late Pleistocene (at approximately $0.7 \mathrm{Ma}$ ) mangrove cover decreased strongly and the montane forests, especially the mid- to upper montane forests, expanded (see Fig. 2 ). A change in composition of lowland taxa may reflect an increase in forest vegetation at the expense of swamp vegetation during the late Pleistocene. At present the altitudinal vegetation zonation in this region is largely associated with the temperature gradient. Apart from a distinctly cooler climate, a possible cause for the much larger montane vegetation cover in the late Pleistocene may be tectonic upheaval. According to Rangin et al. (1990) the Sabah area of northern Borneo saw deformation and uplift throughout the Neogene until the present. On the Zamboanga Peninsula in the southern Philippines tectonic uplift probably continued in the late Pleistocene (C. Rangin, pers. comm., 1990). The montane forests apparently expanded into these newly created highland areas.

Two of the montane taxa have a restricted biostratigraphic range (see Fig. 2). Pollen grains from Dacrycarpus (Podocarpus sect. Dacrycarpus) first appear in the late Pliocene, grains from Phyllocladus first appear approximately $1 \mathrm{Ma}$ in the early Pleistocene. In Cenozoic sediments from northwest Borneo a comparable situation is described by Muller (1966). There, Dacrycarpus appears suddenly from the Pliocene-Pleistocene onward, Phyllocladus first appears around the Pliocene-Pleistocene boundary later than Dacrycarpus.

The present distribution of Phyllocladus and Dacrycarpus includes Borneo, Celebes, the Moluccas, and The Philippines; mostly in highlands forests up to the tree line, but also scattered as low $900 \mathrm{~m}$ for Phyllocladus and $240 \mathrm{~m}$ for Dacrycarpus (de Laubenfels, 1988). Therefore the later arrival of Phyllocladus in the region may have been caused by the absence of highlands of sufficient elevation. However, it cannot be ruled out that Phyllocladus may have a slower migration speed than Dacrycarpus.
The palynological record from Site 767 is (still) fragmentary. The intervals indicated as pollen-rich by the core-catcher samples proved to be not ideal for palynological-paleoecological research. Many samples were barren or had very few sporomorphs. The generally higher pollen concentration of the middle and upper Miocene sediments may linked with the much higher terrigenous organic component of those sediments (larger river/turbidite input). Many of the pollen taxa from the middle and upper Miocene sediments occurred only once or twice and in very low numbers (mostly singly); this severely limited both biostratigraphic and paleoecological information. For instance, a single Alnipollenites vs. (Alnus) grain was found in Sample 124-767B$61 \mathrm{X}-1,50-51 \mathrm{~cm}$ and in Sample 124-767B-60X-6, 149-150 cm. According to Germeraad et al. (1968) this montane pollen type is abundant in Borneo during the Oligocene and the early Miocene. However we can not draw any conclusions from the presence of only two Alnus pollen grains in the Celebes Sea sediments. These could have been derived locally, transported over long distances, or reworked. A more-or-less continues Miocene to Pleistocene palynological-paleoecological record may be obtained if more and larger samples are prepared. Such a record could greatly increase our understanding of the vegetation and climatic history of the area around the Celebes Sea, a region from which only a few palynological-paleoecological studies have been published (Anderson and Muller, 1975; Germeraad et al., 1968; Muller, 1964; 1966; 1968; Morley, 1981).

\section{CONCLUSIONS}

During the middle and late Miocene, extensive wetlands with mangrove forests and coastal and lowland peat swamps covered large parts of the lowland area around the Celebes Sea Site 767.

In the late Pleistocene (at approximately $0.7 \mathrm{Ma}$ ) the wetland area, especially mangrove cover, was strongly reduced. Tectonic uplift may have caused a large expansion of montane forests at approximately $0.7 \mathrm{Ma}$.

Our understanding of Quaternary paleoenvironmental evolution and Miocene to Pleistocene palynostratigraphy in the region may greatly benefit from a detailed study of Site 767 samples.

\section{ACKNOWLEDGMENTS}

The author expresses his gratitude to E. Beglinger, A. Nederbragt, and A. L. Philip for their help and stimulation during the course of the investigation, M. A. Lorente for critically reading the manuscript, and to the Ocean Drilling Program and the Leg 124 shipboard scientists and technicians for collecting the material and making it available for study.

\section{REFERENCES}

Anderson, J.A.R., and Muller, J., 1975. Palynological study of a Holocene peat and a Miocene coal deposit from NW Borneo. Rev. Palaeobot. Palynol., 19:291-351.

de Laubenfels, D. J., 1988. Coniferales. Flora Malesiana, Ser. I: Spermatophy (Flowering Plants) (Vol. 10), Part 3:337-453.

Germeraad, J. H., Hopping, C. A., and Muller, J., 1968. Palynology of Tertiary sediments from tropical areas. Rev. Palaeobot. Palynol., 6:198-348.

Morley, R. J., 1981. Development and vegetation dynamics of a lowland ombrogenous peat swamp in Kalimantan Tengah, Indonesia. J. Biogeogr., 8:383-404.

Muller, J., 1959. Palynology of Recent Orinoco Delta and Shelf sediments. Micropaleontology, 5:1-32.

1964. A palynological contribution to the history of the mangrove vegetation in Borneo. In Cranwell, L. M. (Ed.), Ancient Pacific Floras. Univ, of Hawaii Press, 33-42. 
1966. Montane pollen from the Tertiary of N.W. Borneo. Blumea, 14:213-235.

1968. Palynology of the Pedawan and Plateau Sandstone Formations (Cretaceous-Eocene) in Serawak, Malaysia. Micropaleontology, 14:1-37.

Rangin, C., Bellon, H., Benard, F., Letouzey, J., Müller, C., and Sanudin, $\mathrm{T}$., in press. Neogene arc-continent collision in Sabah, Northern Borneo (Malaysia). In Angelier, J. (Ed.), Geodynamic Evolution of the Eurasian Margin. Tectonophysics.

Rangin, C., Silver, E. A., von Breymann, M. T., et al., 1990. Proc. ODP, Init. Repts., 124: College Station, TX (Ocean Drilling Program).
Somboon, J.R.P., 1990. Palynological study of mangrove and marine sediments of the Gulf of Thailand. J. S.E. Asian Earth Sci., 4:85-97. van der Kaars, W. A., 1989. Aspects of Late Quaternary palynology of eastern Indonesian deep sea cores. Neth. J. Sea Res., 24:495-500.

1990. Late Quaternary vegetation and climate of Australasia as reflected by the palynology of Eastern Indonesian deepsea pistoncores [Ph.D. dissert.]. Univ. Amsterdam.

Date of initial receipt: 29 June 1990

Date of acceptance: 14 December 1990

Ms 124B-132 
APPENDIX

Pollen analysis samples from Celebes Sea Site 767, ODP Leg 124. Total pollen counts are given.

\begin{tabular}{|c|c|c|c|c|c|}
\hline $124-767 \mathrm{~A}-1 \mathrm{H}, \mathrm{CC}$ & 46 & $124-767 \mathrm{~B}-30 \mathrm{X}, \mathrm{CC}$ & 0 & 124-767B-59X, CC & 144 \\
\hline $124-767 \mathrm{~B}-1 \mathrm{H}, \mathrm{CC}$ & 105 & $124-767 \mathrm{~B}-31 \mathrm{X}, \mathrm{CC}$ & 0 & $124-767 \mathrm{~B}-60 \mathrm{X}, \mathrm{CC}$ & 0 \\
\hline $124-767 \mathrm{~B}-2 \mathrm{H}, \mathrm{CC}$ & 96 & $124-767 \mathrm{~B}-32 \mathrm{X}, \mathrm{CC}$ & 0 & $124-767 \mathrm{~B}-61 \mathrm{X}, \mathrm{CC}$ & 0 \\
\hline $124-767 \mathrm{~B}-3 \mathrm{H}, \mathrm{CC}$ & 119 & $124-767 \mathrm{~B}-33 \mathrm{X}, \mathrm{CC}$ & 0 & $124-767 \mathrm{~B}-62 \mathrm{X}, \mathrm{CC}$ & 120 \\
\hline $124-767 \mathrm{~B}-4 \mathrm{H}, \mathrm{CC}$ & 0 & $124-767 \mathrm{~B}-34 \mathrm{X}, \mathrm{CC}$ & 0 & $124-767 \mathrm{~B}-63 \mathrm{X}, \mathrm{CC}$ & 0 \\
\hline $124-767 \mathrm{~B}-5 \mathrm{H}, \mathrm{CC}$ & 60 & $124-767 \mathrm{~B}-35 \mathrm{X}, \mathrm{CC}$ & 0 & 124-767B-64X, CC & 149 \\
\hline $124-767 \mathrm{~B}-6 \mathrm{H}, \mathrm{CC}$ & 110 & $124-767 \mathrm{~B}-36 \mathrm{X}, \mathrm{CC}$ & 0 & $124-767 \mathrm{~B}-65 \mathrm{X}, \mathrm{CC}$ & 0 \\
\hline $124-767 \mathrm{~B}-7 \mathrm{H}, \mathrm{CC}$ & 121 & 124-767B-37X, CC & 0 & $124-767 \mathrm{~B}-66 \mathrm{X}, \mathrm{CC}$ & 0 \\
\hline $124-767 \mathrm{~B}-8 \mathrm{H}, \mathrm{CC}$ & 105 & $124-767 \mathrm{~B}-38 \mathrm{X}, \mathrm{CC}$ & 0 & 124-767B-67X, CC & 0 \\
\hline 124-767B-9H, CC & 111 & $124-767 \mathrm{~B}-40 \mathrm{X}, \mathrm{CC}$ & 0 & 124-767B-68X, CC & 0 \\
\hline $124-767 \mathrm{~B}-10 \mathrm{H}, \mathrm{CC}$ & 0 & $124-767 \mathrm{~B}-41 \mathrm{X}, \mathrm{CC}$ & 0 & $124-767 \mathrm{~B}-69 \mathrm{X}, \mathrm{CC}$ & 0 \\
\hline $124-767 \mathrm{~B}-11 \mathrm{X}, \mathrm{CC}$ & 62 & $124-767 \mathrm{~B}-42 \mathrm{X}, \mathrm{CC}$ & 0 & $124-767 \mathrm{~B}-70 \mathrm{X}, \mathrm{CC}$ & 0 \\
\hline $124-767 \mathrm{~B}-13 \mathrm{X}, \mathrm{CC}$ & 127 & $124-767 \mathrm{~B}-43 \mathrm{X}, \mathrm{CC}$ & 0 & $124-767 \mathrm{~B}-71 \mathrm{X}, \mathrm{CC}$ & 0 \\
\hline $124-767 \mathrm{~B}-14 \mathrm{X}, \mathrm{CC}$ & 18 & $124-767 \mathrm{~B}-44 \mathrm{X}, \mathrm{CC}$ & 158 & $124-767 \mathrm{~B}-72 \mathrm{X}, \mathrm{CC}$ & 0 \\
\hline $124-767 \mathrm{~B}-15 \mathrm{X}, \mathrm{CC}$ & 9 & $124-767 \mathrm{~B}-45 \mathrm{X}, \mathrm{CC}$ & 156 & 124-767B-73X, CC & 0 \\
\hline 124-767B-17X, CC & 2 & 124-767B-46X, CC & 148 & 124-767B-74X, CC & 0 \\
\hline 124-767B-18X, CC & 0 & $124-767 \mathrm{~B}-47 \mathrm{X}, \mathrm{CC}$ & 158 & 124-767B-75X, CC & 0 \\
\hline $124-767 \mathrm{~B}-19 \mathrm{X}, \mathrm{CC}$ & 0 & 124-767B-48X, CC & 179 & 124-767B-76X, CC & 0 \\
\hline 124-767B-21X, CC & 0 & $124-767 \mathrm{~B}-49 \mathrm{X}, \mathrm{CC}$ & 191 & 124-767B-77X, CC & 0 \\
\hline $124-767 \mathrm{~B}-22 \mathrm{X}, \mathrm{CC}$ & 0 & 124-767B-50X, CC & 103 & 124-767B-78X, CC & 0 \\
\hline 124-767B-23X, CC & 0 & $124-767 \mathrm{~B}-51 \mathrm{X}, \mathrm{CC}$ & 218 & $124-767 \mathrm{C}-5 \mathrm{R}, \mathrm{CC}$ & 0 \\
\hline 124-767B-24X, CC & 0 & 124-767B-52X, CC & 126 & $124-767 \mathrm{C}-6 \mathrm{R}, \mathrm{CC}$ & 0 \\
\hline $124-767 \mathrm{~B}-25 \mathrm{X}, \mathrm{CC}$ & 0 & 124-767B-53X, CC & 28 & $124-767 \mathrm{C}-7 \mathrm{R}, \mathrm{CC}$ & 0 \\
\hline 124-767B-26X, CC & 0 & $124-767 \mathrm{~B}-54 \mathrm{X}, \mathrm{CC}$ & 98 & $124-767 \mathrm{C}-8 \mathrm{R}, \mathrm{CC}$ & 0 \\
\hline $124-767 \mathrm{~B}-27 \mathrm{X}, \mathrm{CC}$ & 0 & 124-767B-56X, CC & 4 & $124-767 \mathrm{C}-11 \mathrm{R}, \mathrm{CC}$ & 0 \\
\hline 124-767B-28X, CC & 0 & 124-767B-57X, CC & 1 & $124-767 \mathrm{C}-12 \mathrm{R}, \mathrm{CC}$ & 0 \\
\hline $124-767 \mathrm{~B}-29 \mathrm{X}, \mathrm{CC}$ & 0 & $124-767 \mathrm{~B}-58 \mathrm{X}, \mathrm{CC}$ & 111 & & \\
\hline
\end{tabular}

124-767A-1H-1, 14- $19 \mathrm{~cm}$ $124.767 \mathrm{~A}-1 \mathrm{H}-1,33-38 \mathrm{~cm}$ $124-767 \mathrm{~A}-1 \mathrm{H}-1,60-65 \mathrm{~cm}$ $124-767 \mathrm{~A}-1 \mathrm{H}-1,60-65 \mathrm{~cm}$
$124-767 \mathrm{~B}-1 \mathrm{H}-1,26-27 \mathrm{~cm}$ $124-767 \mathrm{~B}-1 \mathrm{H}-1,52-53 \mathrm{~cm}$ 124-767B-1H-1, 75-76 cm $124-767 \mathrm{~B}-1 \mathrm{H}-1,101-102 \mathrm{~cm}$ $124-767 \mathrm{~B}-1 \mathrm{H}-1,125-126 \mathrm{~cm}$ 124-767B-1H-1, $149-150 \mathrm{~cm}$ $124-767 \mathrm{~B}-1 \mathrm{H}-2,24-25 \mathrm{~cm}$ $124-767 \mathrm{~B}-1 \mathrm{H}-2,52-53 \mathrm{~cm}$ $124-767 \mathrm{~B}-1 \mathrm{H}-2,75-76 \mathrm{~cm}$ 124-767B-1H-2, 99-100 cm $124-767 \mathrm{~B}-1 \mathrm{H}-2,125-126 \mathrm{~cm}$ 124-767B-1H-3, 4-5 cm $124-767 \mathrm{~B}-1 \mathrm{H}-3,25-26 \mathrm{~cm}$ 124-767B-1H-3, 50-51 cm $124-767 \mathrm{~B}-1 \mathrm{H}-3,73-74 \mathrm{~cm}$ $124-767 \mathrm{~B}-1 \mathrm{H}-3,99-100 \mathrm{~cm}$ 124-767B-2H-4, 22-23 cm 124-7678-3H-4, 26-27 cm $124-767 \mathrm{~B}-4 \mathrm{H}-4,25-26 \mathrm{~cm}$ $124-767 \mathrm{~B}-5 \mathrm{H}-4,25-26 \mathrm{~cm}$ 124-767B-5H-6, 17-22 cm $124-767 \mathrm{~B}-6 \mathrm{H}-4,22-23 \mathrm{~cm}$ $124-767 \mathrm{~B}-7 \mathrm{H}-4,26-27 \mathrm{~cm}$ 124-767B-8H-3, 29-31 cm $124-7678-8 \mathrm{H}-4,3-4 \mathrm{~cm}$ 124-767B-9H-2, 126-128 cm 124-767B-9H-4, 1-2 cm 124-767B-10H-4, 26-27 cm 124-7678-13X-2, 37-39 cm 124-767B-15X-3, 9-14 cm 124-767B-19X-2, 35-40 cm 124-767B-21X-7, 9-14 cm $124-767 \mathrm{~B}-27 \mathrm{X}-2,108-110 \mathrm{~cm}$ 124-767B-29X-5, 140-142 cm 124-767B-33X-3, 98-100 cm $124-767 \mathrm{~B}-33 \mathrm{X}-7,20-22 \mathrm{~cm}$ 124-767B-36X-5, 60-62 cm 124-767B-39X-4, 8-10 cm $124-767 \mathrm{~B}-42 \mathrm{X}-1,4-5 \mathrm{~cm}$ 124-767B-42X-3, $98-100 \mathrm{~cm}$ 124-767B-42X-6, 147-150 cm 124-767B-43X-2, 99-100 cm 124-767B-43X-4, 34-36 cm 124-767B-44X-1, 4-5 cm 124-767B-44X-3, 99-101 cm

\section{Appendix (continued)}

\begin{tabular}{lr}
\hline $124-767 \mathrm{~B}-52 X-4,100-101 \mathrm{~cm}$ & 340 \\
$124-767 \mathrm{~B}-52 X-7,40-42 \mathrm{~cm}$ & 108 \\
$124-767 \mathrm{~B}-53 X-4,48-50 \mathrm{~cm}$ & 120 \\
$124-767 \mathrm{~B}-53 X-7,0-2 \mathrm{~cm}$ & 22 \\
$124-767 \mathrm{~B}-54 X-3,100-102 \mathrm{~cm}$ & 9 \\
$124-767 \mathrm{~B}-54 X-5,12-14 \mathrm{~cm}$ & 3 \\
$124-767 \mathrm{~B}-55 X-1,100-101 \mathrm{~cm}$ & 33 \\
$124-767 \mathrm{~B}-55 X-4,50-51 \mathrm{~cm}$ & 102 \\
$124-767 \mathrm{~B}-56 \mathrm{X}-1,8-9 \mathrm{~cm}$ & 65 \\
$124-767 \mathrm{~B}-56 X-3,97-98 \mathrm{~cm}$ & 43 \\
$124-767 \mathrm{~B}-57 X-1,17-18 \mathrm{~cm}$ & 57 \\
$124-767 \mathrm{~B}-57 X-3,100-101 \mathrm{~cm}$ & 67 \\
$124-767 \mathrm{~B}-58 X-1,3-4 \mathrm{~cm}$ & 30 \\
$124-767 \mathrm{~B}-58 X-3,98-99 \mathrm{~cm}$ & 41 \\
$124-767 \mathrm{~B}-58 X-6,53-54 \mathrm{~cm}$ & 3 \\
$124-767 \mathrm{~B}-59 X-2,50-51 \mathrm{~cm}$ & 48 \\
$124-767 \mathrm{~B}-59 X-4,149-150 \mathrm{~cm}$ & 79 \\
$124-767 \mathrm{~B}-60 X-1,100-101 \mathrm{~cm}$ & 82 \\
$124-767 \mathrm{~B}-60 X-4,50-51 \mathrm{~cm}$ & 15 \\
$124-767 \mathrm{~B}-60 X-6,149-150 \mathrm{~cm}$ & 56 \\
$124-767 \mathrm{~B}-61 X-1,50-51 \mathrm{~cm}$ & 1 \\
$124-767 \mathrm{~B}-62 X-1,50-51 \mathrm{~cm}$ & 96 \\
$124-767 \mathrm{~B}-62 X-3,149-150 \mathrm{~cm}$ & 49 \\
$124-767 \mathrm{~B}-62 X-6,50-51 \mathrm{~cm}$ & 39 \\
$124-767 \mathrm{~B}-63 X-3,50-51 \mathrm{~cm}$ & 22 \\
$124-767 \mathrm{~B}-63 X, C \mathrm{C}$ & 38 \\
$124-767 \mathrm{~B}-64 X-1,50-51 \mathrm{~cm}$ & 20 \\
$124-767 \mathrm{~B}-64 X-3,149-150 \mathrm{~cm}$ & 0 \\
$124-767 \mathrm{~B}-64 X-6,99-100 \mathrm{~cm}$ & 16 \\
$124-767 \mathrm{~B}-65 X-2,149-150 \mathrm{~cm}$ & 0 \\
&
\end{tabular}

In addition, 16 core-catcher samples from Site 768 in the Sulu Sea $\left(08^{\circ} 4^{\prime} \mathrm{N}, 121^{\circ} 18^{\prime} \mathrm{E}\right.$, at a water depth of $4395 \mathrm{~m}$ ) were analyzed. They proved to be practically barren of palynomorphs, the few pollen grains that were found came from a mangrove vegetation (Rhizophora and Sonneratia).

$\begin{array}{ll}124-768 \mathrm{~B}-15 \mathrm{H}, \mathrm{CC} & 124-768 \mathrm{C}-1 \mathrm{R}, \mathrm{CC} \\ 124-768 \mathrm{~B}-17 \mathrm{H}, \mathrm{CC} & 124-768 \mathrm{C}-3 \mathrm{R}, \mathrm{CC} \\ 124-768 \mathrm{~B}-19 \mathrm{H}, \mathrm{CC} & 124-768 \mathrm{C}-6 \mathrm{R}, \mathrm{CC} \\ 124-768 \mathrm{~B}-23 \mathrm{H}, \mathrm{CC} & 124-768 \mathrm{C}-11 \mathrm{R}, \mathrm{CC} \\ 124-768 \mathrm{~B}-26 \mathrm{H}, \mathrm{CC} & 124-768 \mathrm{C}-15 \mathrm{R}, \mathrm{CC} \\ & 124-768 \mathrm{C}-19 \mathrm{R}, \mathrm{CC} \\ & 124-768 \mathrm{C}-22 \mathrm{R}, \mathrm{CC} \\ & 124-768 \mathrm{C}-25 \mathrm{R}, \mathrm{CC} \\ & 124-768 \mathrm{C}-28 \mathrm{R}, \mathrm{CC} \\ & 124-768 \mathrm{C}-34 \mathrm{R}, \mathrm{CC} \\ & 124-768 \mathrm{C}-38 \mathrm{R}, \mathrm{CC}\end{array}$

